\title{
Evaluation of open lung biopsy in critically ill, ventilator dependent intensive care unit patients
}

\author{
Richard Hughes MB BCH FRCA, Glenn McGuire MD \\ Departments of Anesthesia and Critical Care, The Toronto Hospital, Toronto, Ontario
}

\begin{abstract}
R Hughes, G McGuire. Evaluation of open lung biopsy in critically ill, ventilator dependent intensive care unit patients. Can Respir J 1997;4(5):246-250.
\end{abstract}

OBJECTIVE: Evaluation of the benefits and risks of performing open lung biopsy (OLB) in critically ill, ventilator dependent intensive care unit patients.

DESIGN: Retrospective chart review from 1990 to 1995. SETTING: A tertiary care teaching hospital intensive care unit.

INTERVENTION: OLB in patients requiring mechanical ventilation for respiratory failure

MEASUREMENTS: Data collected included preoperative investigations, lung injury score, diagnosis, treatment and eventual outcome.

RESULTS: Twenty-seven patients (14 male, 13 female) were mechanically ventilated before OLB for a median duration of seven days. A change in clinical management occurred in $85 \%$ of the patients as a result of new information obtained from the OLB. There was no statistical difference in overall outcome whether OLB was performed early or later in the course of respiratory failure once the patient was mechanically ventilated. The incidence of perioperative complications was $37 \%$. Ten patients eventually left hospital.

CONCLUSIONS: In a small percentage of intensive care patients refractory to the usual medical treatment modalities, open lung biopsy intervention is required to attempt to obtain a specific diagnosis.

Key Words: Artifical respiration, Biopsy, Critical care, Surgery
Évaluation de la biopsie pulmonaire chirurgicale chez les patients dans un état critique, dépendants d'un respirateur et traités dans un service de soins intensifs

OBJECTIF : Évaluation des bénéfices et des risques de la pratique d'une biopsie pulmonaire chirurgicale chez des patients dans un état critique, dépendants d'un respirateur et traités dans un service de soins intensifs.

MODĖLE : Examen rétrospectif des dossiers médicaux des patients de 1990 à 1995.

CONTEXTE : Service des soins intensifs d'un hôpital universitaire de soins tertiaires.

INTERVENTION : Pratique d'une biopsie pulmonaire chirurgicale chez des patients nécessitant une ventilation mécanique en raison d'une insuffisance respiratoire.

MESURES : Les données collectées comprenaient les investigations préopératoires, la cotation des lésions pulmonaires, le diagnostic, le traitement, et les résultats à long terme.

RESULTATS : Vingt-sept patients (14 hommes, 13 femmes) ont été ventilés mécaniquement pendant une moyenne de sept jours avant de subir une biopsie pulmonaire chirurgicale. On a changé les modalités du traitement chez $85 \%$ des patients à la lumière des nouvelles informations révélées par la biopsie. Il n'y avait aucune différence significative dans le résultat global, que la biopsie pulmonaire chirurgicale ait été pratiquée dès l'installation de l'insuffisance respiratoire ou plus tard, une fois le patient ventilé mécaniquement. L'incidence des complications périopératoires était de $37 \%$. Dix patients ont finalement pu quitter l'hôpital.

CONCLUSIONS : Pour un petit pourcentage de patients traités aux soins intensifs et qui ne répondent pas au traitement médical habituel, il est nécessaire de pratiquer une biopsie pulmonaire chirurgicale pour essayer d'obtenir un diagnostic spécifique.

Correspondence: Dr Glenn McGuire, Department of Anesthesia, The Toronto Hospital, Western Division, 399 Bathurst Street, Toronto, Ontario M5T 2S8. Telephone 416-603-5202, fax 416-603-6494 
$\mathrm{O}$ pen lung biopsy (OLB) is performed as a diagnostic investigation in acute or chronic disease of the lungs presenting as pulmonary infiltrates. It may be carried out either for localized or generalized pulmonary disease. Various bronchoscopic procedures can be performed to ascertain a specific diagnosis of lung disease. These include bronchoalveolar lavage, protected brush specimens or transbronchial lung biopsy, but open lung biopsy is considered the 'gold standard' $(1,2)$.

The use of OLB as a diagnostic procedure in nonintensive care unit (non-ICU) patients who are both immunosuppressed and immunocompetent with diffuse parenchymal lung disease has been studied extensively. In this population, OLB is a relatively safe technique to perform and provides a specific diagnosis on which to base treatment strategy in the majority of cases (66\% to $91 \%$ ) (3-6). The efficacy of performing an OLB in critically ill, ventilator dependent patients in an ICU is less well defined. However, a potential higher incidence of morbidity and mortality associated with OLB in this high risk population has led to the dilemma of whether an OLB is indicated for such patients in whom a change in overall prognosis may not be realized despite identification of a specific diagnosis (3). Biopsies performed at this late stage of the disease process may show the changes of generalized lung injury from which it may be difficult to obtain a specific pathological diagnosis.

\section{PATIENTS AND METHODS}

The study protocol was approved by The Toronto Hospital Ethics Committee for Research on Human Subjects. The authors retrospectively studied their experience with OLBs in mechanically ventilated ICU patients at The Toronto Hospital over six years (1990 to 1995). Patients who had the human immunodeficiency virus were excluded, and all patients included in the study were mechanically ventilated for at least two days before the performance of an OLB. The medical records department searched for all charts with reference to the phrase 'lung biopsy, open' using the ICD-9-DM classification. Percutaneous and endoscopic lung biopsies were not included.

Data were obtained regarding age, sex, reason for admission to the ICU, investigations performed pre-OLB, therapy instituted to treat respiratory failure and duration of ventilation before biopsy. A measurement of the degree of acute lung injury was made immediately before OLB by means of the Murray score (7). The site biopsied was noted. Complications, impact on treatment, duration of ventilation after OLB and mortality were documented. The biopsy reports were reviewed for histological and microbiological data. Routine processing of pathological specimens included hematoxylin and eosin staining for morphology, elastic trichrome stain for fibrous tissue and Gomori methenamine silver stain for fungus or pneumocystis. Routine microbiology included staining and cultures for bacteria, fungus and tuberculosis. Other testing was available by request at the time of the biopsy.

Results from the study were analyzed using an unpaired $t$-test for analysis of the effect of patient age compared with eventual outcome and $\chi^{2}$ test with Yates' correction for $2 \times 2$ tables for comparing all other variables with hospital mortality. Results were considered statistically significant if $\mathrm{P}<0.05$.

\section{RESULTS}

Twenty-seven patients were included in the study: 14 male and 13 female with ages ranging from 22 to 80 years with a mean of 57 . The patients were initially mechanically ventilated for reasons including respiratory failure secondary to pneumonia $(n=21)$, postcardiac arrest $(n=2)$, postelective surgery $(n=3)$ and nonpulmonary sepsis $(n=1)$. Table 1 lists the presumed causes of ongoing respiratory failure requiring lung biopsy. The median duration of ventilatory support before undergoing OLB was seven days with a mean of 14 days (range two to 65). Most of the patients underwent respiratory investigations before surgical intervention with OLB was considered necessary. Ten patients $(37 \%)$ had a computed tomography scan of the chest and 23 (85\%) had a brochoscopy and bronchoalveolar lavage, with transbronchial biopsy in two of these patients (7.4\%). Pharmacological therapy instituted at some time before OLB consisted of antibiotics in 26 patients (96\%), empirical steroid therapy in 14 patients $(51 \%)$ and cyclophosphamide in four $(15 \%)$, with three patients receiving acyclovir and one receiving amphotericin.

The mean Murray lung injury score immediately before OLB was 2.54 (range 0.25 to 3.75 ). Fifteen of the patients had a high Murray score, greater than 2.5 indicating severe lung injury. The mode of ventilation used differed among the patients: eight were on assist control, three on intermittent mandatory ventilation, eight on pressure control, three on high frequency jet ventilation and five on pressure support ventilation alone. All the OLBs were performed using a general anesthetic in the operating room. Biopsies were obtained using a limited anterolateral thoracotomy with 19 (70\%) being performed on the left and eight (30\%) on the right.

The most notable aspect of the surgery was a high incidence of perioperative complications (Table 2). Ten patients (37\%) experienced significant complications as a result of the OLB. There were no deaths directly attributed to perioperative complications.

All biopsies were histologically abnormal with 17 (63\%) revealing a specific pathological diagnosis. Bronchiolitis obliterans organizing pneumonia (BOOP) was the most common (Table 3). Using microbiological examination, three patients were identified to have a bacterial infection in addition to generalized inflammation. Therefore, 20 patients $(74 \%)$ had either a pathological or microbiological diagnosis made. A specific pathological diagnosis was obtained in nine of 10 patients in whom more than one lobe of lung was biopsied. This compares with a specific diagnosis in only eight of the remaining 17 patients where a single lobe of lung was sampled. Multiple lobe biopsies appear to increase the probability of obtaining a specific diagnosis from OLB.

Acting on the information gained from the OLB, a management change was made in 23 of the 27 patients $(85 \%)$. Steroids were added in 11 patients, increased in four and stopped in one patient. Antibiotics were stopped in 13 pa- 
TABLE 1

Patient characteristics

\begin{tabular}{|c|c|c|c|c|c|c|c|c|}
\hline Patient & Age & Sex & $\begin{array}{c}\text { Presumed cause } \\
\text { of respiratory } \\
\text { failure }\end{array}$ & $\begin{array}{l}\text { Associated } \\
\text { medical } \\
\text { illness }\end{array}$ & $\begin{array}{c}\text { Days from } \\
\text { intubation to OLB }\end{array}$ & Murray score & $\begin{array}{l}\text { Preoperative } \\
\text { diagnostic } \\
\text { procedures }\end{array}$ & $\begin{array}{c}\text { Days of IPPV } \\
\text { post OLB }\end{array}$ \\
\hline 1 & 62 & $F$ & Pneumonia & - & 5 & 3.75 & BAL & 8 \\
\hline 2 & 43 & M & Pneumonia & $\begin{array}{c}\text { Single lung } \\
\text { transplant }\end{array}$ & 65 & 2.0 & BAL, CT scan & 10 \\
\hline 3 & 67 & $\mathrm{~F}$ & $\begin{array}{l}\text { Interstitial lung } \\
\text { disease }\end{array}$ & $\begin{array}{c}\text { Mesotheliom, } \\
\text { ATN }\end{array}$ & 5 & 2.0 & BAL & 2 \\
\hline 4 & 61 & $\mathrm{~F}$ & BOOP & Scleroderma & 43 & 1.5 & BAL, CT scan & 25 \\
\hline 5 & 22 & $\mathrm{~F}$ & Pneumonia & Tuberculosis & 7 & 2.75 & BAL, CT scan & 12 \\
\hline 6 & 43 & $M$ & Pneumonia & - & 3 & 2.75 & BAL, CT scan & 4 \\
\hline 7 & 32 & $\mathrm{~F}$ & Vasculitis & Pyelonephritis & 6 & 2.0 & BAL, CT scan & 35 \\
\hline 8 & 58 & $\mathrm{~F}$ & Pneumonia & $\mathrm{CHF}$ & 6 & 2.0 & BAL, CT scan & 3 \\
\hline 9 & 54 & $M$ & Pneumonia & NIDDM & 7 & 2.25 & BAL, CT scan & 1 \\
\hline 10 & 45 & $\mathrm{M}$ & Pneumonia & - & 3 & 2.75 & BAL, CT scan & 5 \\
\hline 11 & 73 & $\mathrm{~F}$ & Pulmonary fibrosis & Hyperthyroid & 28 & 3.5 & & 10 \\
\hline 12 & 69 & $\mathrm{~F}$ & Pneumonia & $\begin{array}{l}\text { Hypertension, } \\
\text { NIDDM }\end{array}$ & 4 & 2.75 & & 7 \\
\hline 13 & 78 & M & $\begin{array}{l}\text { Atypical } \\
\text { pneumonia }\end{array}$ & $\begin{array}{l}\text { Hypertension, } \\
\text { NIDDM }\end{array}$ & 7 & 3.25 & BAL & 3 \\
\hline 14 & 60 & $\mathrm{~F}$ & Pneumonia & $\begin{array}{l}\text { Angina, } \\
\text { non-Hodgkins } \\
\text { lymphoma }\end{array}$ & 7 & 3.5 & BAL, TBB & 12 \\
\hline 15 & 69 & $\mathrm{M}$ & $\begin{array}{l}\text { Interstitial lung } \\
\text { disease }\end{array}$ & CHF, UGIB & 12 & 3.25 & BAL, CT scan & 13 \\
\hline 16 & 80 & $\mathrm{M}$ & Pneumonia & $\mathrm{CHF}, \mathrm{SDH}$ & 9 & 2.75 & BAL, CT scan & 7 \\
\hline 17 & 69 & $\mathrm{M}$ & Pneumonia & ATN & 5 & 2.75 & BAL & 10 \\
\hline 18 & 32 & $\mathrm{M}$ & Vasculitis & $\begin{array}{c}\text { Miliary } \\
\text { tuberculosis }\end{array}$ & 45 & 0.5 & BAL, CT scan & 23 \\
\hline 19 & 47 & M & Pneumonia & $\begin{array}{c}\text { Double lung } \\
\text { transplant }\end{array}$ & 12 & 2.5 & $\begin{array}{c}\text { BAL, CT scan, } \\
\text { TBB }\end{array}$ & 21 \\
\hline 20 & 48 & $\mathrm{~F}$ & Lymphoma & $\begin{array}{l}\text { Non-Hodgkins } \\
\text { lymphoma }\end{array}$ & 41 & 2.5 & BAL, CT scan & 13 \\
\hline 21 & 66 & $\mathrm{~F}$ & $\begin{array}{l}\text { Atypical } \\
\text { pneumonia }\end{array}$ & - & 10 & 1.75 & BAL & 16 \\
\hline 22 & 30 & $\mathrm{~F}$ & $\begin{array}{l}\text { Atypical } \\
\text { pneumonia }\end{array}$ & $\begin{array}{l}\text { CHF, SLE, } \\
\text { ESRF }\end{array}$ & 3 & 0.25 & & 35 \\
\hline 23 & 75 & M & Pneumonia & - & 5 & 3.75 & BAL & 10 \\
\hline 24 & 70 & M & Pneumonia & $\begin{array}{l}\text { Alcoholism, } \\
\text { CVA }\end{array}$ & 7 & 3.0 & BAL, CT scan & 16 \\
\hline 25 & 68 & $\mathrm{M}$ & $\begin{array}{l}\text { Interstitial lung } \\
\text { disease }\end{array}$ & $\begin{array}{c}\text { Pulmonary } \\
\text { fibrosis, } \\
\text { asthma }\end{array}$ & 7 & 3.25 & BAL & 15 \\
\hline 26 & 79 & $M$ & Pneumonia & Angina, ATN & 10 & 2.5 & BAL & 4 \\
\hline 27 & 57 & $\mathrm{~F}$ & Pneumonia & Angina & 2 & 3.0 & - & 1 \\
\hline
\end{tabular}

ATN Acute tubular necrosis; BAL Bronchoalveolar lavage; BOOP Bronchiolitis obliterans organizing pneumonia; CHF Congestive heart failure; CT Computed tomography; CVA Cerebral vascular accident; ESRF End-stage renal failure; F Female; IPPV Intermittent positive pressure ventilation; M Male; NIDDM Noninsulin dependent diabetes mellitus; OLB Open lung biopsy; SDH Subdural hematoma; SLE Systemic lupus errythmatosis; TBB Transbronchial biopsy; UGIB Upper gastrointestinal bleed

TABLE 2

Perioperative complications of patients undergoing open lung biopsy

\begin{tabular}{lc}
\hline Complication & Number of patients \\
\hline Persistent air leak through the chest tube postoperatively & 5 \\
Postoperative pneumothorax & 1 \\
Postoperative hemorrhage (more than $500 \mathrm{~mL}$ blood loss in first $24 \mathrm{~h}$ ) & 1 \\
Perioperative myocardial infarction & 1 \\
Intraoperative desaturation (oxygen saturation $<90 \%$ or $\mathrm{PaO}_{2}<60 \mathrm{mmHg}$ ) and persistent air leak postoperatively & 1 \\
Intraoperative hypotension (more than $20 \%$ reduction in blood pressure) and postoperative pneumothorax & 1 \\
\hline
\end{tabular}


TABLE 3

Diagnosis and management changes postopen lung biopsy (OLB)

\begin{tabular}{|c|c|c|c|c|c|}
\hline Patient & Post OLB diagnosis & Steroid change & Antibiotic change & Other change & Outcome \\
\hline 1 & BOOP & Add & Stop & - & Left hospital \\
\hline 2 & BOOP & - & - & - & Left hospital \\
\hline 3 & Lymphoproliferative disease & Add & Stop & - & Left hospital \\
\hline 4 & $\mathrm{DAD}$ and serratia infection & - & Add & - & Left hospital \\
\hline 5 & Miliary tuberculosis & - & Change & - & Left hospital \\
\hline 6 & Benign lymphocytic angitis & Increase dose & Stop & Add cyclophosphamide & Left hospital \\
\hline 7 & Idiopathic hemosiderosis & Stop & - & - & Left hospital \\
\hline 8 & Interstitial fibrosis & - & - & - & Left hospital \\
\hline 9 & Nonspecific interstitial pneumonia & - & - & - & Left hospital \\
\hline 10 & Generalized inflammation & Same dose & Stop & - & Left hospital \\
\hline 11 & BOOP & Add & Change & - & Died -10 days \\
\hline 12 & BOOP & Increase dose & Stop & - & Died -7 days \\
\hline 13 & $\begin{array}{c}\text { Interstitial pneumonitis and fibrosing } \\
\text { alveolitis }\end{array}$ & Add & Stop & - & Died -3 days \\
\hline 14 & $\begin{array}{l}\text { Acute exudative process with chronic } \\
\text { pneumonitis }\end{array}$ & Add & Change & - & Died -12 days \\
\hline 15 & $\begin{array}{c}\text { Acute on chronic interstitial lung } \\
\text { disease }\end{array}$ & Add & Stop & & Died -31 days \\
\hline 16 & $\begin{array}{l}\text { Rapidly progressive pulmonary } \\
\text { fibrosis }\end{array}$ & - & - & Add cyclophosphamide & Died -7 days \\
\hline 17 & Actively progressive fibrosis & Add & Change & - & Died -10 days \\
\hline 18 & Necrotising vasculitis & Increase dose & Stop & - & Died -45 days \\
\hline 19 & Acute rejection of lung transplant & Increase dose & Start & $\begin{array}{l}\text { Decrease } \\
\text { cyclophosphamide }\end{array}$ & Died -21 days \\
\hline 20 & DAD & - & Stop & - & Died -13 days \\
\hline 21 & DAD and pneumocystis pneumonia & - & - & - & Died -16 days \\
\hline 22 & Nonspecific inflammation & - & Stop & - & Died -35 days \\
\hline 23 & Active interstitial inflammation & Add & Stop & - & Died -10 days \\
\hline 24 & Interstitial fibrosis & Add & Stop & - & Died -16 days \\
\hline 25 & $\begin{array}{l}\text { Progressive fibrosis and pulmonary } \\
\text { embolus }\end{array}$ & Add & Stop & Add heparin & Died -15 days \\
\hline 26 & $\begin{array}{c}\text { Acute pulmonary embolus and } \\
\text { organizing fibrosis }\end{array}$ & Add & - & Withdrawal of care & Died -4 days \\
\hline 27 & Bronchoalveolar carcinoma & - & - & Withdrawal of care & Died - 1 day \\
\hline
\end{tabular}

BOOP Bronchiolitis obliterans organizing pneumonia; DAD Diffuse alveolar damage

tients, changed in four and added in two. Other pharmacological alterations were the addition of heparin in two patients, addition of cyclophosphamide in two and a decrease in the dose of cyclophosphamide in one patient. Of the 20 patients with a specific diagnosis, two patients had active treatment withdrawn and 11 patients died as a result of their disease. A comparison was performed between the 11 patients in whom the OLB was performed within the first seven days of ICU stay and the 16 patients in whom the OLB was performed later in their course. No difference in eventual outcome was found from performing the biopsy early $(\mathrm{P}=0.24)$. There was no statistically significant difference in patient survival with specific biopsy results compared with nonspecific biopsy findings.

After undergoing OLB, patients remained mechanically ventilated for one to 35 days with a median of 10 days and a mean of 12 days. Fifteen patients died in ICU, two died on the ward after successful weaning from ventilation and discharge from the ICU, and 10 patients (37\%) subsequently left hospital.

There was a significant difference $(\mathrm{P}<0.05)$ in age of sur- vivors versus nonsurvivors following OLB. The average age of survivors was 48 years compared with 63 years for nonsurvivors.

\section{DISCUSSION}

OLB in mechanically ventilated patients is often considered a last resort to obtain a diagnosis for a patient in whom empiric therapy for respiratory failure has failed. Despite obtaining a specific diagnosis in a majority of patients (74\%) after OLB, there was no statistically significant difference in patients' eventual overall outcome. Information gained from an OLB necessitated a management change in $85 \%$ of patients, with $37 \%$ of patients eventually leaving hospital. In a previous ICU study, Warner et al (8) found that in both spontaneously breathing and mechanically ventilated patients, despite a specific diagnosis being determined in $66 \%$ of patients from OLB, the overall survival to leaving hospital was $30 \%$.

There was no significant difference if the OLB was performed within the first seven days of instituting mechanical ventilation. This may be because patients could have been on 
the ward for several days before requiring mechanical ventilation and by the time the patients require ICU therapy the disease process is well advanced, resulting in fibrosis and generalized inflammation. A similar-sized study by Lachapelle et al (9) found a significant benefit to performing OLB early in the course of respiratory failure, but not all patients in the study were mechanically ventilated before the OLB.

This study demonstrated that age was a determinant of survival after OLB. The mean age of survivors was statistically significantly lower than that of nonsurvivors. This is in all likelihood due to an decreased incidence of intercurrent medical problems in addition to respiratory failure and more pulmonary reserve in the younger population.

The risk of complications related to OLB is a consideration. The incidence of complications has been reported as between $11 \%$ and $19 \%$ in series of patients undergoing OLB $(1,8)$. However, these are largely in patients who were not mechanically ventilated preoperatively. It is of great concern

\section{REFERENCES}

1. Walker WA, Cole FH, Khandekar A, Mahfood SS, Watson DC. Does open lung biopsy affect the treatment in patients with diffuse pulmonary infiltrates? J Thorac Cardiovasc Surg 1989;97:534-40.

2. Bove P, Ranger W, Pursel S, Glover J, Bove K, Bendick P. Evaluation of outcome following open lung biopsy. Am Surg 1994;60:564-70.

3. Canver CC, Mentzer RM. The role of open lung biopsy in early and late survival of ventilator-dependent patients with diffuse idiopathic lung disease. J Cardiovasc Surg 1994;35:151-5.

4. Chechani V, Landreneau R, Shaikh SS. Open lung biopsy for diffuse infiltrative lung disease. Ann Thorac Surg 1992;54:296-300.

5. Venn GE, Kay PH, Midwood CJ, Goldstraw P. Open lung biopsy that 10 patients (37\%) in our study developed perioperative complications. The majority of these complications were persistent air leaks through the chest tube associated with notable surgical emphysema, but others occurred during the surgery, either hypotension or arterial hypoxemia. In previous studies the perioperative complication rate for performing OLB on ICU patients was reported to be between $10 \%$ and $40 \%(3,9)$.

In conclusion, the majority of patients requiring mechanical ventilation for respiratory failure never require OLB. In a small percentage of patients refractory to the usual medical treatment modalities, this surgical intervention is required to obtain a specific diagnosis. OLB may be of benefit in confirming potentially steroid responsive disease. However, in mechanically ventilated patients, there is also a higher incidence of OLB-associated complications. This study confirmed the observations made in several other papers that obtaining a specific diagnosis does not necessarily lead to an improved overall survival.

in patients with diffuse pulmonary shadowing. Thorax 1985;40:931-5.

6. Nelems JM, Cooper JD, Henderson RD, Peng T, Phillips MJ. Emergency open lung biopsy. Ann Thorac Surg 1976;22:260-4.

7. Murray JF, Matthay MA, Luce JM, Flick MR. An expanded definition of the adult respiratory distress syndrome. Am Rev Respir Dis 1988;138:720-3.

8. Warner DO, Warner MA, Divertie MB. Open lung biopsy in patients with diffuse pulmonary infiltrates and acute respiratory failure. Am Rev Respir Dis 1988;137:90-7.

9. Lachapelle KJ, Morin JE. Benefit of open lung biopsy in patients with respiratory failure. Can J Surg 1995;38:317-21. 


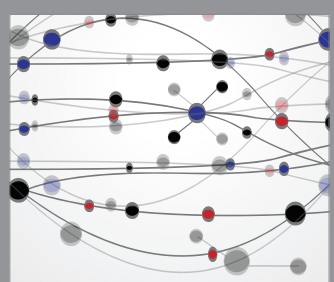

The Scientific World Journal
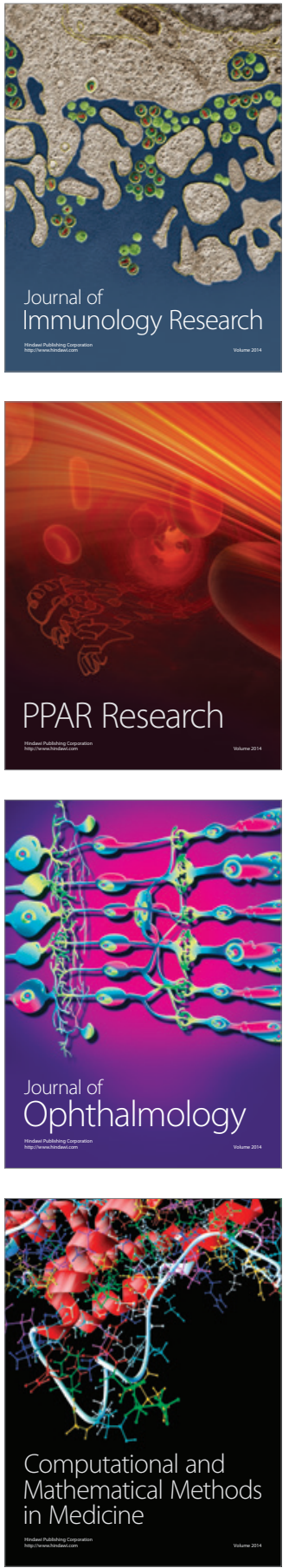

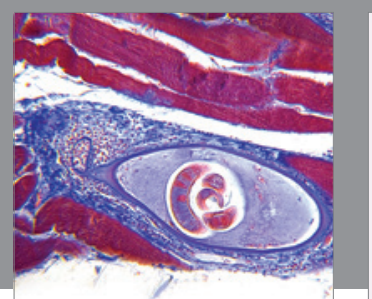

Gastroenterology Research and Practice

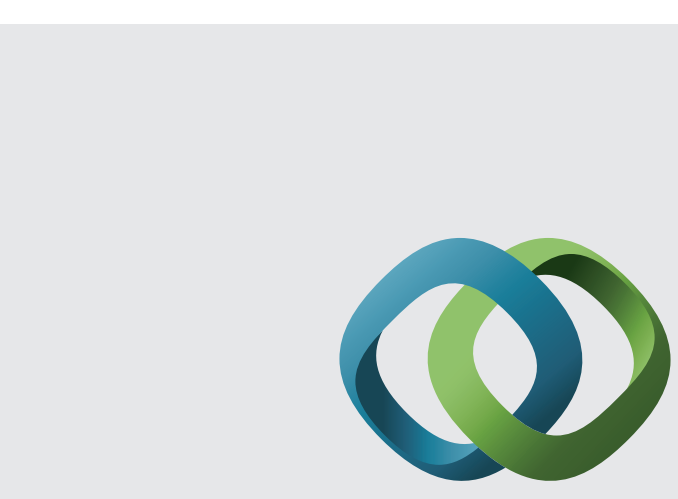

\section{Hindawi}

Submit your manuscripts at

http://www.hindawi.com
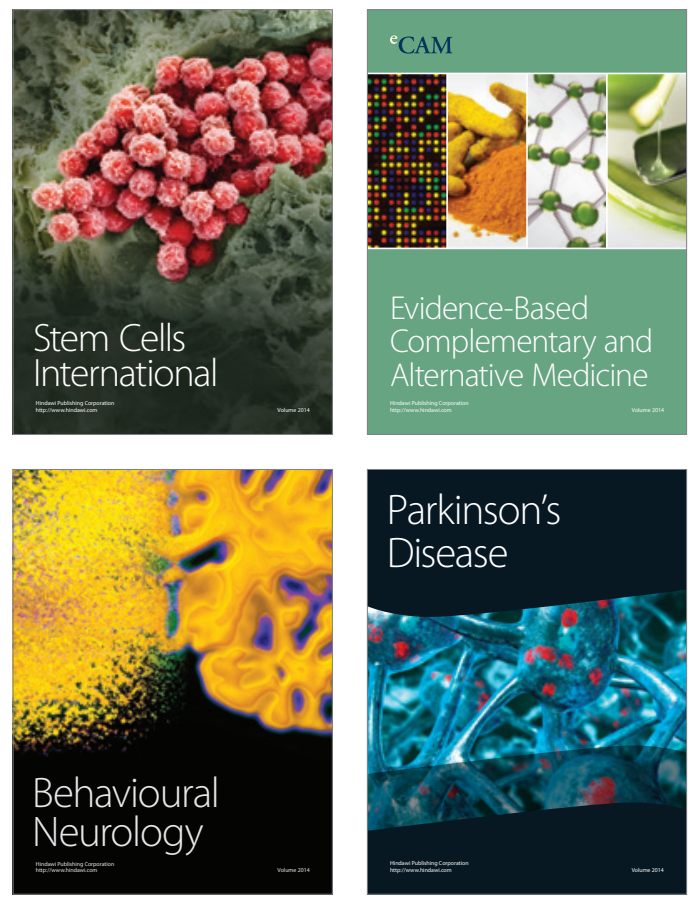
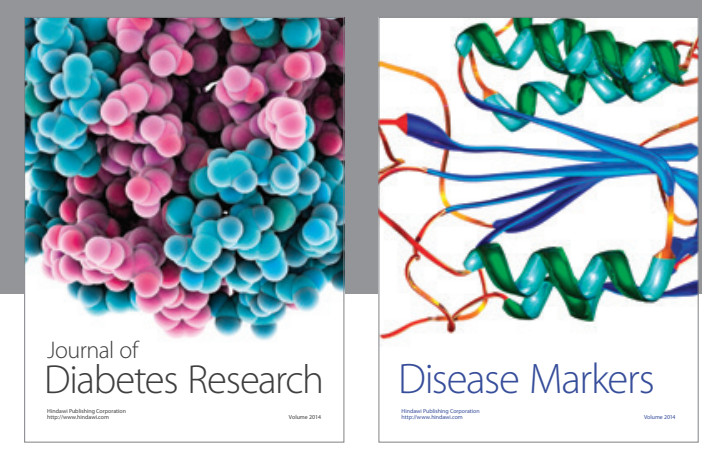

Disease Markers
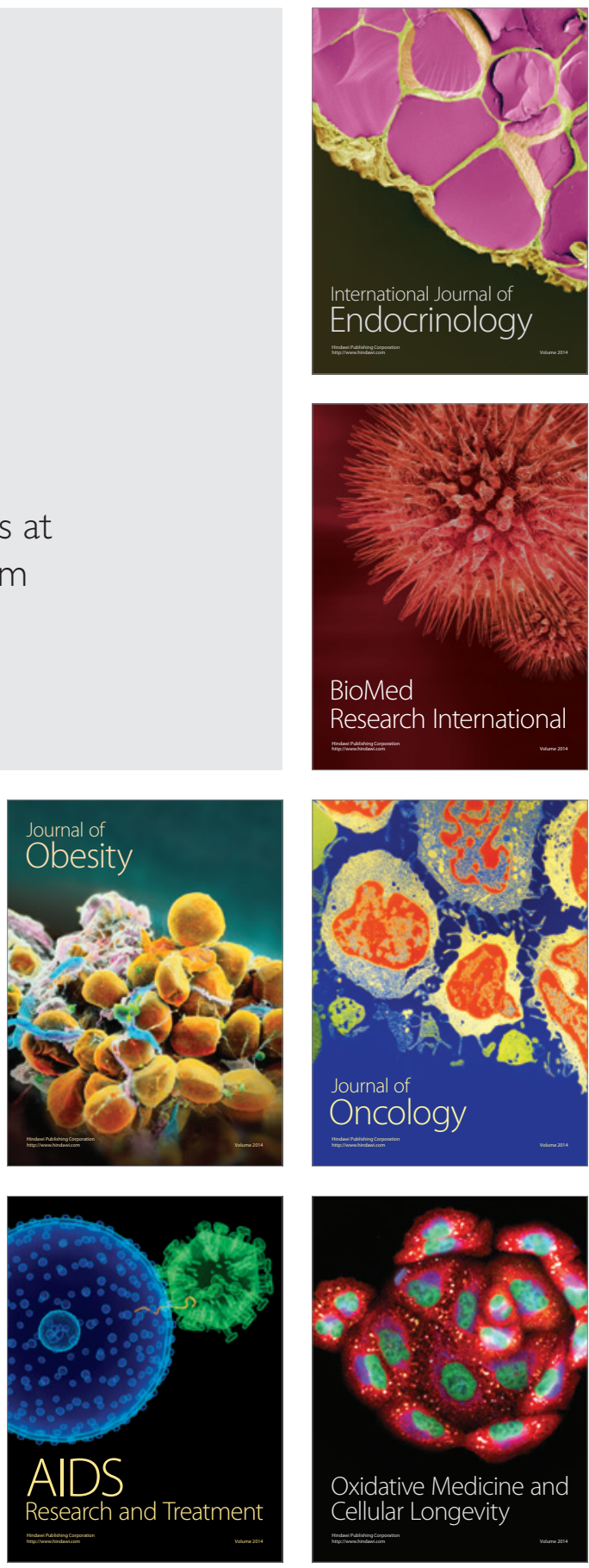